\title{
The Radical Voice of Margaret Oliphant: Extending Domesticity in Hester
}

\section{and Kirsteen}

The author was awarded a $\mathrm{PhD}$ in 2018 for a thesis exploring how nineteenth-century writers Margaret Oliphant and Elizabeth Gaskell drew on their domestic identities as wives and mothers to write in radical, yet subtle, ways which had the potential to inform and educate their young female readership. Central to the thesis was the concept of 'extended domesticity', an expanded version of the domestic space which offered all women, including those whose lives did not fit into the Victorian ideal of marriage and maternity, the opportunity to forge their own identities, educate themselves, and find personal fulfillment. The author's research interests include the work of nineteenth-century women writers, representations of female sexuality, domesticity, women and work, unconventional families, and 'writing spaces'. 


\section{The Radical Voice of Margaret Oliphant: Extending Domesticity in Hester and Kirsteen}

This paper demonstrates how the nineteenth-century writer Margaret Oliphant drew upon her domestic identity to write in radical ways which could educate and inform her young female readership. Through the exploration of two female characters, Catherine Vernon in Hester (1883) and Kirsteen Douglas in Kirsteen (1890), the paper demonstrates how Oliphant represented the importance of opportunities available for young women within 'extended domesticity', a version of the domestic space which extended beyond conventional boundaries to include all women. Through representations of female characters like Catherine and Kirsteen, who had careers and even businesses, of their own, Oliphant showed the possibilities available for women whose lives did not fit into the conventional mould of marriage and maternity. Hester and Kirsteen allow Oliphant to represent two very different versions of domesticity, and to reinforce the necessity for an extended version of it, which allows women the space to find personal growth and fulfilment. The paper engages with the scholarship of critics such as George Levine and Katherine Mullin to explore Oliphant's radical voice and to reinforce her place as an important writer.

Keywords: Margaret Oliphant; nineteenth century; domesticity; women; work

This essay aims to reinforce Margaret Oliphant's importance as a nineteenth-century writer. Far from being conventional in her opinions of women's lives, Oliphant instead can be seen as possessing a radical voice among her contemporaries. Along with her successful writing career, Oliphant's roles as a wife and a mother enabled her to use her skills to negotiate and even influence, changing attitudes to women in the nineteenth century. Through the examples of two of Oliphant's female characters, Catherine Vernon from Hester (1883) and Kirsteen Douglas from Kirsteen (1890), this essay will explore how Oliphant used her familial, domestic experiences to write in 'radical' ways. Both Catherine and Kirsteen show signs of the New 
Woman of the period, and their enterprising actions and apparently unconventional lives help Oliphant to educate and inform her young female readership about possible careers. I will explore how, through female characters like Catherine and Kirsteen, Oliphant showed the necessity of an extended version of the domestic space to enable women to grow and become fulfilled. She emphasised the damaging repercussions for women who did not have a nurturing domestic space from which to grow and develop. Each novel offers very different versions of the domestic space. In Hester, Oliphant provides an example of a problematic domestic environment, fraught with difficulties as family members reveal their petty jealousies, resulting in stifled growth and impeded development for the novel's central female characters, Catherine and Hester. In the later novel, Kirsteen, however, Oliphant presents an entirely different domestic space. Instead, she draws a strong link between a nurturing, congenial domestic space and women's development in terms of personal growth, showing that domestic life can lead to a meaningful career. Once Kirsteen escapes the stifling and oppressive environment of her father's home, the domestic space she inhabits with Miss Jean is the opposite of Catherine's and Hester's because it is extended, and enhanced, reinforcing the possibilities available to women to nurture their potential.

Before going on to examine the concept of an extended domestic space, I will briefly explain how my evaluation of Oliphant's importance as a writer adds to the field of Oliphant scholarship. In a 2016 essay, 'Taking Oliphant Seriously: A Country Gentleman and His Family', George Levine argues for Oliphant's place as a significant and underrated nineteenthcentury novelist. ${ }^{1} \mathrm{He}$ analyses her dedication to representing ordinary experience throughout her novels and short stories, suggesting that her strength lies in her ability to register every day domestic experience and all of its difficulties. While Levine's arguments are useful and valid in the exploration of the intricacies of Oliphant's radical voice, I further his ideas by looking at how Oliphant not only remains dedicated to the domestic space, but how her novels extend 
that space, suggesting that ordinary domesticity can be a useful tool for helping women to forge their own identities and careers out in the public sphere. Tamara S. Wagner, too, discusses the ways in which Oliphant represents her female characters' knowledge of business matters outside of the domestic space. ${ }^{2}$ Though Wagner's debate explores Oliphant's desire to represent female intelligence, I also consider how this enables her to demonstrate the irrational taboo which exists around the possibilities for women's roles in the public sphere. Indeed, Oliphant evidences women's abilities in business roles through female characters such as Catherine and Kirsteen, both of whom are in the domestic and the public spaces simultaneously. Margarete Rubik also explores Oliphant's 'subversive potential' as a female writer whose intelligent and confident female characters did not always fit into the Victorian ideal of 'the submissive angel in the house.' ${ }^{3}$ Though Rubik looks to Oliphant's representation of work as an important element of women's lives, she considers her depiction of domesticity as a return to convention, rather than, as I argue, an important and progressive space for women to find personal growth, education and fulfilment.

Within her novels Oliphant demonstrated the possibilities for expanding the domestic space beyond its conventional boundaries so that it belonged to all women, a place where they could be apparently unconventional while also simultaneously appearing to conform to aspects of conventionality. I name this 'extended domesticity', a term which considers an expanded version of the domestic, offering room for women to educate themselves and find personal fulfilment and growth. Though the domesticity of the home was conventionally seen as the rightful place of nineteenth-century women, rather than view it as restrictive, Oliphant demonstrated that it had the potential to be a space which woman could use to their advantage. For Oliphant, extended domesticity represented a platform from which women could develop a life which could include a career and even the forging of a 'public' identity in the realm of business. In her novels and short stories, Oliphant asserted radical ideas in representing the 
possibilities of extended domesticity for women to forge spaces which, while not within the public sphere, were not wholly within the domestic either. Extended domesticity thus allowed women to move beyond the expected realms of Victorian domestic space. This could be physically represented through a room within the home where, for example, writers such as Oliphant could sit down and write, or where women could begin to hone a skill and consider a career. In psychological terms, extended domesticity allowed women to realise that the home did not have to be a confined space but could be a starting point from which they could expand their own identities.

Oliphant's feelings towards her own life and the importance she places on gaining experience are present in her Autobiography when she compares her writing with that of Charlotte Brontë. Though Oliphant admits that she feels her work to be 'perfectly pale and colourless beside [Brontë's]', she stresses the importance of her own 'life experience [and] fuller conception of life' which she believes is vitally important, not only in daily living, but also in writing. ${ }^{4}$ It is Oliphant's belief in the importance of experience, and what it brings to her writing, which makes her novels so useful as educative tools for her readers. While she is reticent about her writing's value when compared with writers such as Brontë, her comments suggest an underlying belief in what her experience can offer her readers. This makes her work a valuable guide to reflection and psychological growth. Without prescribing answers or solutions, Oliphant leaves her readers room to consider, decide, and understand the situations they encounter in their novels. In her fiction Oliphant initiates an education process which has the potential to be triggered by readers' own thoughts and feelings, and which is perhaps more powerful and effective than conventional education as a result.

Oliphant's writing demonstrates that she was keen to make a departure from traditional nineteenth-century views of female experience. Her voice was radical not only because she did not shy away from discussing topics such as choices for women regarding marriage, children, 
and a career, but also because of the subtle ways she managed to have that discussion while remaining within the boundaries of Victorian notions of propriety. Oliphant's version of feminism was subtle and unique. While it did not overtly attempt to break through social constructs, it had the potential to influence her young female readers, by encouraging them to consider broadening their outlook on life and contemplate a wider range of life choices; choices in marriage, maternity, and a career. As a result of her belief in the importance of the domestic space, Oliphant challenged ideas of prescribed domestic roles for women. While Victorian society usually condemned middle-class women to remain within the domestic sphere, whether they wanted to be there or not, Oliphant complicated this notion by emphasising the importance of the domestic in relation to well-being, self-awareness, and personal growth. Through her female characters, she radically represented domestic space as the rightful domain of all women, regardless of their experience. This meant that as well as the conventional wife and mother, Oliphant showed that the domestic space could offer opportunities for the personal growth and development of women whose lives did not fit into the Victorian ideal of marriage and maternity.

Levine looks to Oliphant's location between conventionality and unconventionality; a tension, I will argue, which is reflected not only within her own life but in her literary works, also. ${ }^{5}$ Significantly, Levine suggests that Oliphant is interested in 'the desperate need of women $[\ldots]$ for a life beyond the routine $[\ldots]$ a life that allows for growth and change' and that this need is associated directly with her 'subversive' recognition of the limits of marriage and motherhood. ${ }^{6}$ Oliphant's subtle recognition of the potential that exists for women to feel unfulfilled despite having what society presents as an ideal, that is a marriage and family, is, I will argue, central to her representation and extension of the domestic space within her writing. By extending the domestic sphere so that it becomes a space for personal fulfilment, growth and education, Oliphant provides examples of women who achieve the 'growth and change' 
her fiction illustrates. ${ }^{7}$ Levine suggests that Oliphant's novels, particularly her later ones, sit as comfortably with the modernists as they do with the mid-century realist writers precisely because they 'put to the most serious question' issues such as marriage and motherhood. ${ }^{8} \mathrm{I}$ agree with Levine that the novels can be read as proto-modernist, not only because they represent women who have opportunities and choices beyond maternity and marriage (although this is important) but also because they provide examples of women who enjoy domestic lives within an extended domestic situation and even combine a domestic career with the world of female enterprise, moving women towards the public space.

The importance of female enterprise is explored in Katherine Mullin's book Working Girls, an examination of late nineteenth and early twentieth-century representations of working women in the fiction of this period. Mullin discusses Oliphant's radicalism via her provision of 'alternative feminist prototypes' in what she calls her 'explosion of gender roles'. ${ }^{9}$ Using as her primary example Oliphant's novel of 1892, The Cuckoo in the Nest (although Mullin's ideas could refer to many of Oliphant's female characters), Mullin looks to Oliphant's 'often contradictory attitudes to late-Victorian feminism' which saw her producing female characters who are radically 'experimental' and even 'sexually equivocal'. ${ }^{10}$ Importantly, Mullin explores Oliphant's representation of women who, like The Cuckoo in the Nest's Patty Hewitt, are enterprising in business in order to survive and flourish. Women such as Patty adopt working roles (Patty is a barmaid) which place them on the periphery of the public space, where Oliphant endows them with the agency to develop their own minds and sensibilities. In 1883 , Oliphant published Hester. One of the novel's central female characters and 'feminist prototype' Catherine Vernon, ensured there was no mistaking the author's radicalism. ${ }^{11}$ Not only does Catherine, an unmarried woman, single-handedly support a large extended family, she is also the head of her family's bank, Vernon's. Oliphant represents Catherine as a highly capable woman with a successful career. Yet Catherine's success and ability breed resentment 
and jealousy amongst her family members and dependents, some of who rely on her financially and live in her home, the White House, known locally as the 'Vernonry'. In Hester, Oliphant demonstrates the problems inherent in a domestic environment which is disrupted, upset, and fraught with tension, rather than an open space, extended and filled with possibilities for women. This problematic domesticity is reinforced through the situation of Catherine's ward, Hester. By the end of the novel, Hester is left with marriage as the only realistic prospect for her future, despite proving her potential as a future businesswoman by assisting Catherine to prevent the near downfall of the bank. In Hester, Oliphant makes clear the necessity of a congenial domestic space, by highlighting the issues faced by women when their version of domesticity is stifled and oppressive.

Early in the novel, when Catherine has saved the bank and spent several years running it as successfully, if not more so, than her grandfather, the narrator pauses to question whether it is 'genius for business, as distinct as genius for poetry, which makes everything succeed? But this is more than any man can be expected to understand'. ${ }^{12}$ Oliphant makes the point from the beginning of the novel that Catherine's 'genius' for running the bank is a result of her enterprising and capable nature which can be innate in some women, as it is in some men. Oliphant reinforces here the idea that hard work, determination and persistence are crucial to success; qualities she herself became used to over the course of her career. Aeron Hunt discusses how 'Catherine's position as the main action of the novel opens blends masculine and feminine: in her life "the work of a successful man of business" is increased yet softened by all the countless nothings that make business for a woman' ${ }^{13}$ It is this duality that Oliphant represents through Catherine; the assimilation of her domestic life with her role as a businesswoman; an assimilation made more complex by a domestic environment fraught with familial rivalries and resentment. It is Catherine's (and indeed, Oliphant appears to suggest, many women's) 'genius' to manage successfully a domestic existence which requires as much 
time and effort as a public role. For Oliphant domesticity could include looking after a husband and children, managing an extended family, or even looking after oneself. Indeed, she suggests, that this management of all roles is 'more than any man [could] be expected to understand' because it would not usually be expected of a man. ${ }^{14}$ It is women's ability to manage both domestic and public roles, Oliphant reiterates, which is the true 'genius' and Catherine's role as an enterprising woman makes her more than a 'man of business', she is a woman of business able to cope with a career, but has also to manage a complex and difficult extended family. The so-called 'countless nothings' of her domestic life are as important to her as her role heading the bank, just as Oliphant's domestic life and the raising of her children were as important to her as her writing career.

Catherine's negotiation and management of her domestic space means she gathers her family together in the White House, thereby uniting her private home with that of the public arena of the bank. Known as 'Aunt Catherine to a great many people', she manages to assimilate her familial role with that of 'Catherine Vernon, Head of Vernon's Bank'. ${ }^{15}$ Catherine's success as a businesswoman enables her to offer homes to her extended family. Though this act of generosity is representative of Catherine's financial achievement, her success in business breeds resentment amongst those who live under her roof. Relatives such as Mildmay Vernon and the Miss Vernon-Ridgways have invented their own 'picture' of Catherine, which misrepresents her kindness as an underhand attempt to humiliate and undermine them at all costs. ${ }^{16}$ Distrustful not only of Catherine, but also of each other, their hypocrisy prevents the domestic environment of the Vernonry from becoming a place of growth and fulfilment. Instead, it is a place of narrow-minded hostility, with its residents unwilling to view Catherine as a successful businesswoman, instead jealously undermining and belittling her achievement. Much like Oliphant, whose publishing success translated into financial gains for her family, so Catherine's achievements in business translate into success 
for her family, yet their selfishness transforms this success into something to be feared and reviled, rather than applauded. Through the example of the Vernonry, Oliphant provides a representation of a challenging domestic environment, which does not aid women like Catherine or Hester, to expand their horizons. Instead, the residents' resentment reinforces old conventions, suggesting that women who step out of expected domestic norms are subversive and to be distrusted. However, Oliphant's sympathetic portrayal of Catherine and Hester prompts her to propose the radical view that both could flourish successfully in careers and family life if they inhabited a congenial domestic environment. While in her later novels, Oliphant shows women with careers, her earlier novel, Miss Marjoribanks (1866), shows a young woman with a command of her domestic space. ${ }^{17}$ Lucilla Marjoribanks's control of her domestic life allows her to take part, to a limited extent, in the public sphere. Lucilla lives in, and manages, the expanded boundaries of domesticity. Though she does not have a career in the conventional sense, she is highly enterprising, using her social skills to forge a new role which allows, as Levine argues, 'a life beyond the routine [...] a life of growth and change.'18 Lucilla's domestic environment is congenial and productive, providing her with an insight into the public sphere beyond her home.

It cannot be denied that Catherine's success is problematic for her nephew, Edward, who, like the other family members at the Vernonry, 'had not been able to divest himself of a certain grudge against the author of his good fortune'. ${ }^{19}$ Despite her efforts, he cannot reconcile Catherine's role as his guardian within the domestic sphere with her role as his manager in business. The relationship Catherine has with Edward, who despite being her favourite goes on to betray her and almost destroy the bank for a second time, is reminiscent of the relationship Oliphant had with her own sons whose lives were wasted through excessive drinking, gambling, and profligacy despite their mother's best efforts to help them. ${ }^{20}$ It was this relationship and its constant struggles which Oliphant 'drew upon to write the quasi-mother- 
son relationship between Catherine and Edward. ${ }^{21}$ Such honesty in her work, the kind of honesty which has its roots in lived experience, reinforces Oliphant's 'commitment to the direct and faithful confrontation of ordinary experience'. ${ }^{22}$ She does not try to steer her readers away from the possibly difficult realities involved in managing both a career, and a domestic existence. Rather, she provides examples of situations and relationships that are trying and even at times troubling, to show her readers the possibilities that exist for overcoming problems and managing successfully in both private and public spaces despite hardship.

It is no coincidence then that once Edward's betrayal is revealed, Catherine's most important investment is made in Hester, her cousin John's daughter. Though the two share a fraught relationship throughout the novel, they eventually come to amicable terms when Edward absconds, abandoning them both. In the final chapter of the novel, Oliphant's radical voice can be perceived during a conversation between Catherine and Hester in which the two discuss Hester's uncertain future. Catherine tells Hester that 'It is a great pity [...] a girl like you, that instead of teaching or doing needlework, you should not go to Vernon's, as you have a right to do, and work there' ${ }^{23}$ Oliphant's ironic tone can be heard in the conversation between the older woman and her young ward. Despite Catherine's example as the head of the bank, and Hester's demonstration of her business intelligence when she aids Catherine in its rescue, society deems that no such career can be available to Hester without a marriage. Catherine's sentiment regarding women's working roles echoes Oliphant's own in her essay 'The Condition of Women' (1858) when she discusses how women, particularly unmarried women, are often forced into becoming 'half-starved needlewomen, [...] [and] poor governesses' because other more lucrative professional positions 'remain in the possession of men' ${ }^{24}$

Like Catherine who has lived her life as an unmarried woman, and despite Hester's knowledge that without a husband, her life will be difficult and uncertain, the young woman insistently declares that she 'will never marry!'. ${ }^{25}$ Though Catherine recognises Hester's ability 
in business, she responds with regret, telling her that she believes her refusal to choose a husband is 'a great pity. ${ }^{26}$ Catherine's distress at Hester's decision again reveals Oliphant's ironic tone. Though Oliphant recognises that young women should have choice over their marital decisions, and that they should also have the option to work in the same professions as men, she is aware of the reality that while women live in a domestic environment which does not afford room for personal growth, and instead restricts women to a life of dependency, such a choice will not be. ${ }^{27}$ While Hester proves herself as more than capable of helping Catherine to save her business, as an unmarried young woman, relying on Catherine for her home and stability, she is simply another of Catherine's dependents. Hester enables Oliphant to show the problems inherent in restrictive domestic environments which create vulnerability and tension for young women. That Hester is left by the end of the novel with no other choice but marriage (or a refusal of marriage and the uncertainty it brings), despite proving her professional acumen and intelligence, reinforces Oliphant's suggestion that progressive and expansive domestic environments are necessary if women are to find personal fulfilment, and importantly, to make their own choices.

Another female character who forges a public identity appears in Oliphant's novel Kirsteen, 1890. Certainly, Kirsteen Douglas was one of Oliphant's most important attempts at creating a female character who exemplified women's movement into the public sphere towards the close of the century. As a young, enterprising woman, Kirsteen moves out of the domestic space and to another city hundreds of miles away to forge a new identity as a career woman within the public space.

Kirsteen is a skilled needlewoman, whose talent is made clear early in the novel when she embroiders a handkerchief for the man to which she is secretly betrothed, Ronald, using 'a long thread of her red hair' which she fashions into his initials. ${ }^{28}$ Though her skilful sewing is representative of the talent which is to make Kirsteen's future career, the emotional intent 
behind it also demonstrates her latent sexuality. As Mullin suggests about The Cuckoo in the Nest's Patty Hewitt, Kirsteen also enables Oliphant to consider a young woman who acknowledges her sexuality, therefore complicating 'Oliphant's apparently conservative sexual politics. ${ }^{29}$ Although, as Beth Harris points out, 'Oliphant does not openly address sexuality, the troubling implications of Kirsteen's situation seethe just beneath the surface of the text. ${ }^{30}$ The 'troubling implications' Harris discusses, refer not to 'troubling' sexuality, but rather to 'the household domination exercised by Drumcarro [Mr Douglas, Kirsteen's father, the laird of the Drumcarro estate] [which] stifle[s] women's individuality, independence, and ultimately integrity. ${ }^{31}$ Indeed, I would suggest that what Oliphant represents through Kirsteen's hidden expression of her sexuality is not a fearfulness for what female sexuality represents, but rather a questioning of domestic spaces (such as Drumcarro's estate) which do not allow young women to grow and find fulfilment either personally or professionally.

Oliphant's radicalism is made apparent when she demonstrates Kirsteen's choice not only to leave her home, but to go to London to stay with the housekeeper Marg'ret's sister, Miss Jean. Like Catherine, who recovered herself from the terrible blow dealt by Edward when she realised she must act to save the bank for a second time, Kirsteen demonstrates the same kind of independent resolve. She 'saw the sudden flash of the resolution, the clearing away of all clouds, the rise of the natural courage $[\ldots],{ }^{32}$ The confined domestic space of Drumcarro's home does not offer her 'room of her own' to grow. Instead, Kirsteen's 'resolution' leads her to realise that the crucial freedom and 'room' she needs to prosper in exists beyond her family home and out in the city. Kirsteen's resolution enables Oliphant to demonstrate how a life trapped in the confines of a difficult and unyielding family home is as unfulfilling as being imprisoned in an unrewarding and unequal marriage.

Kirsteen demonstrates a new generation of young working women who show many signs of the New Woman of the period. She connects her sewing skills with her independent 
and enterprising qualities to 'learn to be a mantua-maker to support myself'. ${ }^{33}$ For Kirsteen dressmaking is a 'trade', not simply a means to an end. Indeed, dressmaking is a trade in the same way a man may enjoy his own professional work; Oliphant suggests that too often fulfilling careers 'remain in the possession of men'. ${ }^{34}$ As Harris points out, Kirsteen's 'iteration of her wish to work mark[s] [...] a willingness to acknowledge [...] the step she is taking - she is a woman who has chosen to work for her living, who has chosen to learn a trade'. ${ }^{35}$ Kirsteen's determination to work is exemplified through her straightforward assertion that her move to London is 'not to see the world, but to make my fortune'. ${ }^{36}$ Oliphant suggests, radically, that women can use their skills in trade to make their own money and support themselves financially (much as she did through the sales of her novels). Kirsteen can turn her dressmaking skill into a commodity by selling the dresses she makes. Kirsteen's suggestion that she will learn from Miss Jean's skill as she carves out her new identity in the public space reinforces the importance Oliphant places on education and women's abilities to educate each other.

Like Catherine and Hester, Miss Jean and Kirsteen share a relationship which involves the younger woman learning valuable skills from the elder which help her to forge her own position within the public sphere. Like Catherine, Miss Jean runs and manages her own business and is an older woman with an independent and respected public role. By including such reciprocal relationships between older and younger women in her novels, Oliphant makes clear the importance of enterprising and experienced women passing on their knowledge to the younger generation. She reiterates the possibilities available for enterprising women to use their talents in business and to forge a career. While Miss Jean had 'been very successful in her day', she was now 'wise enough to perceive the gifts of her young assistant'. ${ }^{37}$ She realises the importance of Kirsteen's modern and forward-thinking approach which will help to take the business into the future and she enjoys how the young girl uses her dressmaking skills to create new 'special effects' (p. 197) and fashions of which she is unaware. Oliphant's radical voice 
can be heard loudly here, because she actively considers Kirsteen's (and indeed all young women's) career opportunities and options. As Oliphant's novels set out to educate their young female readers, she demonstrates here the possibilities which exist when older, knowledgable women pass on their skills and educate future generations of women who take these skills forward to further their trade.

Kirsteen's public identity is denoted by her new moniker of 'Miss Kirsteen'. The removal of her surname is significant because, as Christine Bayles Kortsch points out, it signifies a removal from her father and the 'unimaginative, unpaid sewing [he] demanded'. ${ }^{38}$ More than this, the removal of the Douglas name extricates Kirsteen from her father's values and even her role trapped within his uninspiring and confining version of domesticity. As 'Miss Kirsteen', Kirsteen is given a new identity, one which signifies her newly-forged public role and the one which she uses to embark upon her dressmaking career. Significantly, 'Miss' reinforces Kirsteen's position as an unmarried woman, a status that never changes throughout the novel. As Ann Heilmann points out, 'although her unmarried state is not a deliberate choice, but the result of tragic circumstances, Oliphant implies that it is only as a single woman that Kirsteen has been able to achieve what she wants from life'. ${ }^{39}$ Indeed, the swift ending of Kirsteen's and Ronald's promised union means that she is free to expand her skills and is not confined to the domestic space as a married woman. Her title as 'Miss Kirsteen' is important when Kirsteen returns to her family home to take care of her dying mother. Her new and successful public identity means she does not feel obliged to embody the daughterly, domestic role which was imposed on her in the past, making her free to bring her public identity into her father's home. Like Catherine, who is financially solvent and in a position to help her family, Kirsteen's financial gains means she can assist her father by offering to buy back some of the Douglas family land he had lost. Kirsteen's return to her father's home is as an enterprising and independent woman who does not require his family name to succeed. 
In his exploration of another of Oliphant's novels, A Country Gentleman and his Family, Levine discusses the near impossible relationship between two of the novel's central characters, Theo Warrender and his wife, Lady Markland. Trapped in a marriage that offers her no respite from her jealous and immature husband's demands, Lady Markland is stifled and oppressed. Levine's comments on Theo's jealousy, I feel, resonate with the relationship between Kirsteen and her father, when he suggests that it is 'everything about [her] that implies she has a self of her own, that marks her as different, [...] that suggests she has more experience [...] and is entitled to an independent judgment [which] becomes disenchanting and an obstacle to be obliterated. ${ }^{40}$ Like Theo Warrender, Drumcarro is angered by Kirsteen's new identity which is completely removed from her past life as his daughter. Veiled as deep shame that his name should be embroiled in her 'miserable trade', Drumcarro's true feelings are closer to envy and jealousy that his daughter has experience of working in London and a clear sense of judgment which reaches far beyond his own. ${ }^{41}$ By removing herself from her father's stifling version of domesticity, Kirsteen has not only forged a new and successful identity in the public sphere, she has also become financially stable in her own right. Moving to London, to the enriching and nurturing space of Miss Jean's home, Kirsteen flourishes and develops her entrepreneurial skills. Miss Jean's home is an example of a positive domestic environment which fosters Kirsteen's abilities as a skilled needlewoman and encourages her to develop her own career. When she buys back of the 'old Douglas lands' (p. 336) she does so in the form of a business transaction. Her success as an enterprising woman allows her to use 'Miss Kirsteen', her new (and indeed, public) identity, as a title for the land. Kirsteen's return to the domestic space of her father's home ironically signifies her disassociation from it. By using her identity as a businesswoman to make the purchase of the family land, Kirsteen proves her business acumen has nothing to do with her father's confined domesticity. Kirsteen's choice to offer financial assistance to her father strengthens her role as an independent and enterprising woman 
with a public identity of her own. Not only has Kirsteen made a success of her business, her financial security allows her to assist her father. Rather than sacrificing anything of herself, the offer she makes highlights Kirsteen's success and reinforces how far she has moved away from her father's rigid version of the domestic. While he requires her financial help, she no longer requires his.

Through her successful business acumen, Kirsteen has both reclaimed and added to the domestic space which had earlier confined her. Indeed, Kirsteen is one of Oliphant's most radical female characters, who 'share[s] many characteristics and aspirations with those of the younger, explicitly feminist New Woman writers. ${ }^{42}$ Not only does she move out of a domestic situation which offers her no possibilities for freedom or personal growth, she also fashions an entirely new identity within the public sphere, using her skills to expand her trade and run her business. Oliphant 'establishes her heroine as an artist, taking the needlewoman full circle from the dangerous and dark days of the sweat-shop to a talent which would evoke femininity [...] represented as a source of strength' ${ }^{43}$ Kirsteen is Oliphant's most radical example of the possibilities available for women to move beyond stifling and oppressive domestic spaces and into environments which are nurturing, supportive and encouraging.

In conclusion, for Oliphant, the representation of choice for women in marriage and a career was important, and she shows how this representation can only be achieved through a progressive and enlightened version of domesticity. Throughout her novels and short stories, she provides examples of women who exist in very different versions of the domestic space, and whose lives are different as a result. Characters such as Catherine and Kirsteen embody characteristics of the New Women that Oliphant apparently criticised in her journalism, gaining an erroneous reputation as an anti-feminist in the process. Nevertheless, as I have argued, Oliphant's radicalism was evident to those who chose to read her fiction carefully. As such her position as an important nineteenth-century woman writer is one which is well deserved. 
Word count - 6082 
${ }^{1}$ George Levine, "Taking Oliphant Seriously: A Country Gentleman and his Family," ELH, Vol. 83.1, (2016): 253-258; George Levine, "Reading Margaret Oliphant," Journal of Victorian Culture, Vol. 19.2, (2014): 232246.

2 Tamara S Wagner, "'Honour! That's for men": Satirizing Gender and Genre Confines in Margaret Oliphant's Phoebe Junior', Nineteenth-Century Gender Studies, Vol. 7.3, (2011): 23-38.

${ }^{3}$ Margarete Rubik, The Novels of Mrs Oliphant: A Subversive View of Traditional Themes (New York: Peter Lang, 1994), 113.

${ }^{4}$ Margaret Oliphant, The Autobiography of Margaret Oliphant, ed. Elisabeth Jay (Ormskirk: Broadview Press, 2002), 43

${ }^{5}$ Levine, 'Taking Oliphant Seriously,' 253-258.

${ }^{6}$ Ibid., 233-234.

7 Ibid., 233.

8 Ibid., 236.

${ }^{9}$ Katherine Mullin, Working Girls: Fiction, Sexuality, and Modernity (Oxford: Oxford University Press, 2016), 211.

${ }^{10}$ Ibid.

${ }^{11}$ Ibid., 211.

${ }^{12}$ Margaret Oliphant, Hester (Oxford: Oxford World's Classics, 2009), 22.

${ }^{13}$ Aeron Hunt, Personal Business: Character and Commerce in Victorian Literature and Culture (London: University of Virginia Press, 2015), 161.

${ }^{14}$ Oliphant, Hester, 22.

${ }^{15}$ Ibid., 26.

${ }^{16}$ Ibid., 58.

${ }^{17}$ Margaret Oliphant, Miss Marjoribanks (London: Penguin Classics, 1998).

${ }^{18}$ Levine, "Taking Oliphant Seriously," 233.

${ }^{19}$ Ibid., 50.

${ }^{20}$ Margaret Oliphant, The Autobiography of Margaret Oliphant, ed. Elisabeth Jay (Ormskirk: Broadview Press, 2002) 202-203.

${ }^{21}$ Philip Davis and Brian Nellist, 'Introduction' to: Margaret Oliphant, Hester (Oxford: Oxford World's Classics, 2009), viii-xi.

${ }^{22}$ Levine, "Taking Oliphant Seriously," 233.

${ }^{23}$ Oliphant, Hester, 454.

${ }^{24}$ Margaret Oliphant, "The Condition of Women," Blackwood's Edinburgh Magazine, Vol. 83: (1858) 160.

${ }^{25}$ Ibid.

${ }^{26}$ Ibid., 454.

${ }^{27}$ Ibid., 456.

${ }^{28}$ Margaret Oliphant, Kirsteen (Glasgow: The Association for Scottish Literary Studies, 2010), 244.

${ }^{29}$ Mullin, Working Girls, 211.

${ }^{30}$ Beth Harris, Famine and Fashion (London: Routledge, 2016), 45.

${ }^{31}$ Ibid.

${ }^{32}$ Margaret Oliphant, Kirsteen (Glasgow: The Association for Scottish Literary Studies, 2010)

${ }^{33}$ Ibid., 193.

${ }^{34}$ Ibid.; Oliphant, Kirsteen, 193.

${ }^{35}$ Harris, Famine and Fashion, 47-48.

${ }^{36}$ Oliphant, Kirsteen, 188.

${ }^{37}$ Ibid., 197.

${ }^{38}$ Christine Bayles Kortsch, Dress Culture in Late Victorian Women's Fiction: Literacy, Textiles, and Activism (Surrey: Ashgate Publishing: 2009) 114.

39 Ann Heilmann, "Mrs Grundy's Rebellion: Margaret Oliphant between Orthodoxy and the New Woman," Women's Writing, Vol. 6 (1999), 215-37, 229

${ }^{40}$ Levine, "Taking Oliphant Seriously," 249.

${ }^{41}$ Oliphant, Kirsteen, 336.

${ }^{42}$ Heilmann, "Mrs Grundy's Rebellion," 232.

${ }^{43}$ Ibid., 231.; Roszika Parker, The Subversive Stitch: Embroidery and the Making of the Feminine 
(London: Women's Press, 1984), 197. 